\title{
Jevgenija Dehtjare
}

Dr.oec., as.prof., BA in Tourism program director

ISMA University of Applied Sciences, Riga, Latvia

E-mail: jevgenija.dehtjare@isma.lv

Phone: +371671114518

ORCID: 0000-0003-0993-2579

RESEARCHID: jevgenijadehtjare

\section{Igors Babics}

Mg., $1^{\text {st }}$ level program director "Applied Information Technology"

ISMA University of Applied Sciences, Riga, Latvia

ORCID: 0000-0002-6744-7937

\section{Olga Verdenhofa}

Dr.sc.admin., as.prof.

ISMA University of Applied Sciences, Riga, Latvia

ORCID: 0000-0002-7906-3463

\section{Viktoriia Riashchenko}

Dr.oec., Prof., BA program director

ISMA University of Applied Sciences, Riga, Latvia

ORCID: 0000-0003-1783-3079

\section{A strategy development for a smooth transition into the remote studies in Latvian education institutions in a pandemic}

\begin{abstract}
The aim of the abstract is to investigate challenges the secondary and higher education institutions face during the pandemic times in Latvia and to discuss strategy to be developed in an order to ensure smooth transition into the remote study process with the help of a technological inventory appropriate to be used for remote study process. Challenges both secondary and higher education institutions and their staff experience have to be analysed as well, altogether with the outcomes. A combination of the remote and in-class education, issues and benefits are overviewed in the paper as well. ISMA, the University of Applied Sciences and its transition approach were examined thus establishing strong practical benefit of the research. The research problem is to analyse existing challenges education establishments in Latvia used to face with during the period of pandemic and to examine solution strategy and tools to be applied in an order to establish smooth transition from in-class to a remote study process. The conclusion of the research: no doubts the establishment of the transition process from in present studies into the remote mode was challenging and complicated, however it was realised in a consonance of the frameworks and recommendations designed both by the European and Latvian public bodies. The process of remote studies is challenging, still many advantages were discovered and this let to conclude the approach of combined education has a right to be applied even after the pandemic is over. The outcomes of the research are also beneficial for other educational establishments of Latvia and abroad, thus ensuring known approach when rapid and clear transition strategies must be taken. The developed strategy might be applied in case if there is a necessity to ensure establishment of remote studies within short period of time.
\end{abstract}

\section{Keywords}

education, remote, guidelines, technological tools, Moodle, Zoom, combined approach, pandemic

JEL: I230 


\section{Introduction}

The pandemic hit of COVID-19 to the educational processes within the whole world was sudden and unexpected. The educational establishments faced a necessity to elaborate rapid and effective transition strategies in an order to ensure a switch from in-class into the remote studies. These strategies, firstly applied during a first wave in the Spring 2020 were aligned later on during to lockdowns that used to be applied several times in most of the world's countries. Still, the necessity to adopt remote study process as a part of common education process was admitted long time before.

The research problem is to analyse existing challenges education establishments in Latvia used to face with during the period of pandemic and to examine solution strategy and tools applied in an order to establish smooth transition from in present to remote study process.

Research results: the establishment of the transition process from in present studies into the remote mode was challenging and complicated, however it was realised in a consonance of the frameworks and recommendations designed both by the European and Latvian public bodies. The useful and favourable tools able to ensure the process of remote studies were analysed with the according recommendations, the necessity to continue a combination of remote and in-class studies even after pandemic was stated, the challenges and opportunities for learners, teaching staff and institutions were discussed.

Research limitations: the research was conducted after a first pandemic wave in the spring 2020 and exactly during the second wave during the fall 2020. At the moment this is hard to predict overall impact and challenges that the whole pandemic period will cause to the education at large.

Originality/meaning: this article aims to identify challenges and benefits of the remote and combined study process and a transition strategy to be developed and implemented for the secondary and higher education institutions in Latvia during the pandemic period.

\section{Latest scientific progress and publications review}

In 2016 Finnish educators stated: "Rapid changes in the labour market as well as globalization and the development of the information society have made theoretical environment of higher education more complex." [4]. The next year, 2017, Latvian scientists while analysing trends and strategies to be applied within the Latvian market of higher education establishments, conclude: "distance learning`s popularity around the world is increasing. In Latvia this trend is in the development stage, but local academicians consider that the future of distance learning seems bright" [9]. In fact, they could even imagine how bright the necessity to implement remote study process will shy in the pandemic sky of 2020!

\section{Methods}

Methodological basis includes the following methods: system analysis - used to assess the challenges and benefits of remote and combined study process approach, the literature and legislation acts review according to the establishment of the remote studies process and its control within the EU and Latvia and interviews during a workshop meeting that was held in ISMA University of Applied Sciences (hereinafter ISMA) in October 2020, when both secondary and higher education institutions representatives were met together to discuss the problems of remote studies in Latvia, experiment - implementation of implemented strategy in ISMA.

\section{The purpose of research}

Main objective of the research is the market of educational services of Latvia, implemented both on the levels of secondary and higher education.

Subject of the research - the strategy how to ensure smooth transition from in present into remote study process with the analysis of modern technological tools to be applied as a supportive element with an order to ensure stable and progressive process of remote studies during the pandemic times in Latvia, both on the levels of the secondary and higher education.

\section{Results of the research}

\subsection{REQUIREMENTS TO THE COMPETENCIES OF A MODERN TEACHING STAFF}

Change of educational models and requirements for the types of communication in education imposes on the teacher all the higher requirements for proficiency in the information technology products. Pandemic approach in 2020 led us to admittance of the fact every educator should be able to use modern technological tools in his process of information delivery as a must. No doubts, the pandemic will be over but it will led to unreturnable changes in an approach of education, necessary competences and skills, the whole process of knowledge should be delivered and disseminated. During the pandemic, several lockdowns were and will be applied throughout the world, also in Latvia. Educators first faced the necessity to switch to the online in the spring 2020 , since that time 
they become much better trained for the upcoming lockdowns. They've got practical experience, knowledge and skills to work remotely. Still the education process in Latvia (both in the secondary schools and higher educational institutions (HEI)) faced common problems, such as:

1) Ageing of educators. $51 \%$ of secondary school teachers in Latvia are over 50 years old [11], this leads to impaired ability to gain new skills, especially in accelerated mode;

2) Luck of own in-home devices for education process delivery (mostly in less developed regions of Latvia, not in the capital). Despite the fact the provision of children from lowincome families with portable computers was announced, it is still in transit [6]. Regarding to provision for the appropriate technological tools, such as PC, video cameras, microphones etc. to the teachers and HEI staff it remains as a full responsibility of these people themselves and, optionally, the education institutions where they work.

3) Usage of unlicensed software is related problem with the previous factor.

4) The process of mastering new programs also remains entirely as a responsibility of the teaching staff and the existing potential of the representing school or HEI to ensure these people with according education possibilities.

5) Selection of appropriate technological tools is, in most cases, determined by the representing school or HEI, however teaching staff sometimes is even uninformed about many optional possibilities to be used as a supportive tool to the offered ones.

Disadvantages of remote educational process with existing equipment in the pandemic mode

When teaching staff is remotely separated from its followers (pupils or students) there are several problems recognized while ensuring process of information delivery, its control and monitoring:

1) Remote attendees discipline and control

2) High quality of information delivery process and overall quality of prepared materials

3) Implications with trustful evaluation of knowledge and skills obtained on a distance

The tutor during his remote lecture delivery serves also video-editor, live-streamer, blogger and other functions which may lead to the decrease of his overall teaching qualification as there are too many duties he has to perform at the same time. It is quite complicated mission to prepare online course during short term period, especially without support from the represented educational institution. As we know, the governmental decision to announce lockdown in a country may be immediate and there were cases when the course had to be fully converted into online mode in less than a week.

Advantages of nowadays remote educational process:

1) New experience means brain storming and born of new ideas, methods and tools

2) Modern pupils and students require less socialization nowadays and they found switch to remote mode appropriate and convenient. They can better plan their time, save it as less transportation is required, some may even concentrate on studies better while sitting in a quiet room at their own homes. Remote studies used to be a perfect option for introverts. ISMA own teaching staff observation research showed that remote studies surprisingly increased lectures attendance and eager to perform tasks more attentively.

Professor Ina Blau from Israel`s Open university, finds many advantages of remote education during lockdowns: "It is an opportunity to develop skills," she said. "There is a general societal perception as if students today have a natural affinity to studying in a digital setting since they are exposed to technology from a very early age, what's referred to as 'digital kids." [5]. Blau highlights two primary skills that can be developed by remote learning. The first is digital literacy and the second is self-directed learning. The teacher begins the lesson, provides a general explanation, hands out an assignment and then the children split up into small groups on Zoom, with the teacher switching between chat rooms. The students work together to create or solve something and then present it to the class. Learning has become more active using this method. The Israeli scientist even emphases: she wished to see remote learning combined with regular classwork even after the Covid-19 crisis is behind us. "I hope that starting from grade five, all students will learn for at least a day or two a week from home," she said [5].

A strategy implemented at ISMA University of Applied Sciences in an order to ensure remote and partly remote educational process.

During the first pandemic wave in March 2020, ISMA administration faced urgent necessity to develop and implement a set of measures in an order to ensure smooth but rapid transition into remote mode of education. According to ISMA experience, following steps were implemented:

1) Emergence situation regulation committee was elected. ISMA board, rector, vice rectors, representatives of various departments (study, international etc,) were responsible for guidelines elaboration, information dissemination both among teaching staff and students and regular 
information updates.

2) Guidelines how to organize, implement, monitor and control study process, also remotely and in combined mode (later on during the second pandemic wave starting from the October 2020) were designed and disseminated.

3) Guidelines covered all study process procedures, such as lectures delivery, workshops (due to the LR legislation, during the second pandemic wave it was permitted to deliver important practical components in present [1], exams, final thesis defence, re-examinations and other procedures.

4) ISMA students, both full and part time were switched on to the cloud educational service, Moodle.

5) Communication with students was ensured with the help of related departments (study, international, marketing), ISMA`s website, ISMA pages in social medias (such as Facebook) and Moodle news forum.

6) To ensure regular information broadcasting (such as lectures), it was decided in the spring semester 2020 to establish video recording with the help of Stream Labs software. During the second pandemic wave video recording remains as a supportive tool, however live broadcasts were ensured with the help of Zoom software.

7) ISMA career centre faced the problem to ensure students with internship places. Due to professional qualification to be obtained, ISMA bachelor level programs include internship in their study plans (during the $2^{\text {nd }}, 3^{\text {rd }}, 4^{\text {th }}$ years of studies). Unfortunately, during the pandemic time, especially during the emergency situation and lockdowns many ISMA partners refused to accept students for internship. ISMA faced also problem with international internship in such destinations, as tourism resorts of Spain, Greece, Bulgaria not only because tourism used to stop its activity but also due to restrictions of travel. The problem was solved by development of requirements how to perform internship tasks using mostly tools of statistical analysis, theoretical review and remote staff interviews.

Despite the fact the remote study process was ensured in the shortest time, there were many issues ISMA administration and teaching staff used to face with. Among them it is possible to mention time zone difference between ISMA and Fergana branch (many online lectures were broadcasted too late, so branch students had to watch video records), communication barriers, overloaded IT and study departments aimed to ensure stabile connection, lack of direct contact with the students.

Still there are undoubtedly many advantages present. Huge video records archive covering most of the delivered subjects was created during the shortest time, new technologies were acquired both by the teaching staff and students, and opportunity to work from homes led to saving resources, overall colossal experience was gained.

The developed strategy comes in a consonance with the guidelines to ensure smooth transition into the remote studies, developed by the Organization for Economic Cooperation and Development (Hereinafter OECD). (Reimers F. S. A., 2020). Among the most important measures to be implemented, there are:

1) To establish a responsible committee (administration, lecturers, students, parents ...)

2) Development of schedule, also online

3) Development of a strategy. Priorities: safety, health, knowledge transfer

4) Control and coordination mechanisms

5) Digital Communication (website? Whats App? Forum)

6) Additional options (TV, radio, podcasts, Youtube...)

7) Poor students and their provision

8) Communication between students

9) Teacher training, autonomy

10) Student examinations

11) Food delivery

12) Checking daily attendance (also for the lecturer!)

13) Health safety of the study process sitting behind the computer

14) Communication with other education establishments, exchange of experience

15) Development of a common strategy and follow the plan.

One of the most important tasks for providing qualitative distance education is to ensure qualitative organization of the study process itself, including development of interactive training materials, online lectures and videos, presentations, tests etc. There might be several technological solutions.

Regarding advantages and disadvantages of remote studies and applied technological tools it can be stated following:

1) No doubts the technologies offered for use during the process of providing pupils and students with study materials are already developed enough, however there is a noticeable lack of guidelines which tools to use and how to work with them to achieve best results.

2) There is a need of certain time to update their knowledge and skills both for tutors and learners as they have to be able to switch 
from in-class studies to the remote mode.

3) Guidelines which software to use and how to use those properly must be constantly developed and improved. There should be responsible forces for this action in educational institutions, perhaps, joined groups of IT specialists and representatives of study department, also study program directors etc. - those who manage study process, monitor results and gather feedback both from learners and tutors.

4) During and after pandemic times the most optimal educational format should be combination of in-class education with interactive videos, online lectures, work in cloud environments, such as Moodle and others.

These conclusions come in a full consonance with statements of other abroad colleagues of ISMA, such as Blau's statement of necessity to continue combined approach even after pandemic times.

Regarding to the current situation in the secondary and higher education in Latvia, at the beginning of November 2020, the Ministry Cabinet of the Republic of Latvia announced fully remote studies for the secondary school s classes 7-12, inclass studies for 1-6 classes and partly remote educational process for the higher education institutions. This means, lectures must take place fully remotely meanwhile practical studies (such as workshops etc.) can be effectuated in presence if there is a will to do so by a HEI [1]. However, epidemiological situation changes constantly and by the moment of this article publication these statements could be revised.

Pros for a combined approach in education:

- Interactive materials help a learner to follow the study process in case of his disability to visit a class, for example because of his disease. In addition, recorded video materials will also allow the learner to repeat given material and to get acquainted with it more deeply.

- Repetitive impact and combined approach also mean application of different study tools at once. For example, a learner may require repetitive lecture watching with the help of recorded video in a combination with a follow up of reading a presentation. The assumed knowledge may be checked remotely with the help of online test.

- Tutors are obliged to prepare themselves for video records more thoroughly taking into consideration every phrase may be watched several times. This requires tutors to be much more attentive and their overall performance skills and obtained knowledge increase accordingly. This process leads to common increase of the represented educational institution competitiveness.
- To overall course structure becomes more consistent as all the recorded video materials, presentations and tests should logically complement each other.

- Modern cloud educational systems, such as Moodle allow to follow up both tutors and student's activity within it. This helps a HEI's administration to monitor and control both sides participation in the study process. This also increases students' awareness of the study process and ability to opt for evaluation revise, if necessary.

- In case of tutor's sudden disease or even retirement, the recorded materials allow to the HEI's administration to feel more calmly while looking for a replacement.

- While materials are recorded once, a tutor can use educational tools and approaches more briefly thus increasing the quality of his educational services. The time, necessary for tutor`s self-preparation for studies, decreases.

- A tutor feels more briefly demanding topic achievement confirmation from the learners. Learners are unable to say they`ve missed a part of it due to their absence or other reasons, perhaps, excluding lack of internet connection.

- Combined approach and materials, recorded and uploaded to cloud services as well as learners` ability to reach them on a remote basis give both to process participators and HEIs` administration feeling of comfort and security during unpredictable pandemic times. In case government will oblige educational institutions to switch to a fully or partial remote mode - the institution itself, its teaching staff and students feel much more secure when they all know - everything is ready, recorded, uploaded and it takes only seconds to log in.

Despite the fact the switch to the remote mode was absolutely spontaneous and unpredictable for most of the world's countries during the first pandemic splash in the spring 2020, the overall results of this world wide experiment are tremendous. New approaches were developed; knowledge found a way to be disseminated even remotely, both teaching staff and learner's involvement in the study process was outstanding. New switch to the remote mode that took place during the fall of 2020 didn't raised that much issues and concerns as it was previously. Materials were prepared, conceptual models of remote modes in case of pandemic impact increase were developed and implemented during the situation worsening later on. Both sides already get used to the remote and combined education and studied how to get benefits from the process.

During a workshop "European Answer to 
Pandemic" which was held at ISMA October 9th, 2020 (I., 2020), more than 30 teachers from Riga Secondary Schools and 7 ISMA teaching staff representatives gathered together at ISMA premises to discuss challenges and possible benefits of educational process during pandemic times in Latvia. It was concluded:

- A switch to the remote education process both for Latvian secondary schools and HEIs was rather chaotic. Despite the fact, there were several EU common guidelines developed, Latvian teaching staff has mainly very little information about it, so the development of remote educational process was rather scattered;

- Teaching staff in Latvia felt very little support and, that is more important, lack of clearly explained guidelines by the side of the public bodies;

- Average age and computer skills of teaching staff in Latvia have significant impact on digital tools achievement ability, speed and eager to use;

- Among definitely positive sides it should be mentioned Internet speed and the presence of own digital devices (PC, tablets, laptops) in Latvian house holdings, so there were no many implications for parents to ensure remote educational process;

- However, both, teachers and parents of pupils felt very stressful especially during the first wave of pandemic when the study process was unexpectedly switched to remote even for first year's pupils;

- The experience of remote studies should be continuously applied even after the pandemic will be over. It is highly desirable to provide public guidelines and methodology how to continue implementation of remote and combined studies, elaborated by Latvian Ministry of Education or on the common European level, by OECD.

Still, we have to admit, despite the various and repetitive complaints of the teaching staff about the lack of the recommendations how to operate during the pandemic, these guidelines and legislation acts, reports etc. were developed, some of them even at the even before the peak of the spring pandemic, in anticipation of it. So, there remains a question of its better dissemination with the help of all possible distribution channels. For example, already mentioned Epidemiological precautions to limit the spread of Covid-19 infection [1], Guidelines in person, combined and remote implementation of training [10], Recommendations for universities and colleges precautionary measures to control the spread of Covid-19 infection [3], Supporting the continuation of teaching and learning during the COVID-19 Pandemic [7] and others. The concerns of teachers were about lack of providing clear explanations and simple tutorials, how to implement recommendations.

\section{Conclusions}

During the shortest time the strategy how to ensure the transition into from in-class into the remote studies was designed and implemented at ISMA, in a consonance with EU framework. Benefits and challenges of remote studies were analysed, appropriate tools selected for the smooth remote communication process were examined. Teaching staff, representing both secondary and higher education institutions, involved directly in the process of remote studies was interviewed with according conclusions during the research.

The outcomes of the research are also beneficial for other educational establishments of Latvia and abroad, thus ensuring known approach when rapid and clear transition strategies must be taken. The developed strategy might be applied in case if there is a necessity to ensure establishment of remote studies within short period of time.

To sum up, it should be stated as modern technologies provide us with the broadest opportunities for organizing better educational process. Today we are only at the very beginning of this path. Apparently, humanity will have to go through long and thorny path while remote education in its pure form will surpass full-time education in quality and reliability. Therefore, today and in the future several years seem to be the most effective combined methods of ensuring the educational process.

\section{References}

[1] 360, M. k. 2020, 113 Epidemiologiskēas drošǐbas pasākumi Covid-19 infekcijas izplatības ierobežošanai Retrieved 11 5, 2020 E-source: www.likumi.lv: https://likumi.lv/ta/id/318402-grozijumi-ministrukabineta-2020-gada-9-junija-noteikumos-nr-360-epidemiologiskas-drosibas-pasakumi-covid-19infekcijas-izplati...

[2] I, B 2020 The Technological Inventory of a Modern Teacher. European Answer to Pandemic p 16 Riga: ISMA The University of Applied Sciences

[3] 2020 Ieteikumi augstskolām un koledžām piesardzības pasākumu (aktualizēti 07.11.2020.) Rīga: LR IZM

[4] Jääskelä P N 2016 Models for the development of generic skills in Finnish higher education Journal of Further and Higher Education 42(1) 130-42 
[5] Kabir O 2020.09.26 CALCALIST Retrieved 10 13, 2020 E-source: https://www.calcalistech.com/ ctech/articles/0,7340,L-3851411,00.html

[6] Klūga M 2020.10.15 RE! Retrieved 11 4, 20 E-source: https://www.lsm.lv/raksts/zinas/latvija/ kavejas-portativo-datoru-iegade-skolam-skolas-cer-tos-sanemt-atrak.a378138/

[7] Reimers F, S A 2020 A framework to guide an education response to the COVID-19 Pandemic of 2020 OECD

[8] Reimers F, S A 2020 OECD E-source: http://www.oecd.org/education/Supporting-the-continuationof-teaching-and-learning-during-the-COVID-19-pandemic.pdf

[9] Titareva T 2017 Development Trends in The Higher Education Industry (HEI) in Latvia Riga: RISEBA University of Business, Arts and Technology

[10] Valsts izglītības satura centrs | ESF projekts Nr.8.3.1.1/16/I/002 2020 Vadlīnijas klātienes, kombinētu un attālinātu mācību ìstenošanai Rīga: LR IZM

[11] www.tvnet.lv 2020.11.5 Retrieved 11 5, 2020 E-source: https://www.tvnet.lv/6711633/petijumslatvija-nakamaja-desmitgade-vecuma-del-bus-janomaina-puse-skolotaju 